well known. The rich and interesting Museo Civico di Storia Naturale, of Genoa, amongst its many rarities, contains a magnificent specimen of the Lophiomy's, mounted skin and skeleton, which specimen was caught at Keren in the Bogos land, in June, 1870 , and forms part of the fine collections made at that place by Dr. Beccari and Marquis Antinori. The native name of the Lophiomys, according to Antinori, is Tzechiza.

The reviewer cites $M$. Alphonse Milne-Edwards's impression of the resemblance of Lophiomys to certain opossums, a point in which I cannot completely agree; my impression is that this very remarkable rodent offers one of the best cases of "defensive mimicry," being strangely like a Viverrine carnivore in outward appearance. The granulation of the upper portion of the skull, which extends to the upper surface of the first cervical vertebra, is very peculiar; but it is not strictly correct to assert that nothing of the kind is met with in other mammals; in the very same order, Rodentia, we find a very similar structure in the craniun of the Paca (Calogenys), and I believe some allied forms.

Reale Istituto, Florence, December I7, I879 HeNRY Hillyer Giglioli

\section{On Haloporphyrus lepidion (Risso)}

I HAVE recently had occasion to examine two specimens of this rare and remarkable gadoid fish of the Mediterranean, originally described as Gadus lepidion by Risso ("Ichthyologie de Nice," p. 118). The first was captured in my presence in the Gulf of Genoa, in July last, from a depth of about 900 metres, the second I received from Nice, where it was captured in deep waters on September I last, and I know of a third specimen taken at the latter place. All agree perfectly with Risso's description except in the general colour, a light brown, arid not "un beau rouge incarnat," while Risso appears to have overlooked the presence of a small patch of vomerine teeth. But our Mediterranean specimens present notable differences from that described by Dr. Giinther ("Catalogue of Fishes," iv. p. 358), and referred by him to this species; besides being considerably larger, the British Museum specimen, which is from Madeira, has a much smaller eye and much longer snout and barbel. Such differences might depend on age, but I am strongly inclined to consider then specific, and therefore beg to draw the attention of ichthyologists to the case ; should my opinion prove correct, the Madeiran fish might go by the name of Haloporphyrus gïntheri.

While rapidly completing the rich series of fishes belonging to the central collection of Italian vertebrata, formed by me in the Florence Zoological Museum, I have recently been able to add thereto a second very rare gadoid, the Physiculus dalwigki, Kaup, a new acquisition to the Mediterranean fauna. My specimen was captured at Nice on August 4 last, and strange to say was sent to me as Uraleptus maraldi.

Reale Istituto, Florence

Henry Hilimer Gigliol I

\section{Edison's New Lamp}

I OBSERve in NATURE, vol, xxi. p. 187, a statement to the effect that $\mathrm{Mr}$. Edison has adopted the use of carbon in his new electric lamp, and that the carbon he uses is charred paper or card of the shape of a horse-shoe.

Fifteen years ago I used charred paper and card in the construction of an electric lamp on the incandescent principle. I used it, too, of the shape of a horse-shoe, precisely as, you say, Mr. Edison is now using it. I did not then succeed in obtaining the durability which I was in search of, but I have since made many experiments on the subject, and within the last six month I have, I believe, completely conquered the difficulty which led to previous failure, and I am now able to produce a perfectly durable electric lamp by means of incandescent carbon.

JOSEPH W. SWAN

Underhill, Low Fell, Gateshead, December 29, 1879

\section{Flow of Viscous Materials}

Mr. BotTomLeY, in his paper on this subject in Nature, vol. xxi. p. I59, refers to experiments made four years ago, but if he refers to the Philosophical Magazine, vol. xxvi. 206, I845, he will find a notice of an experiment made twenty-four years ago. It occurred thus : $-A$ barrel of pitch, with one end partly knocked out, had been lying in the yard exposed to the sun for some months, and a part of it had run out on the ground.
My late partner, Prof. L. Gordon, visited the wire-rope works one day in August, I844, and I called his attention to the appearance of the pitch as being a good illustration of Prof. Forbes's theory of glaciers; thereupon he wrote the letter referred to ; which is also quoted in Forbes's "Theory of Glaciers," p. 269.

Any sort of pitch, such as that obtained from gas tar, will answer the purpose. If the surface is rubbed over with some white material, the formation of crevasses will be well shown; and if a row of pins are stuck into the pitch about an inch and allowed to project they will soon lose their perpendicularity and thus indicate the movements in the model glacier. The rapidity of flow of course varies with the temperature.

I had a curious illustration of the power of plants in forcing their way through resisting materials. I had covered the ground with about two inches of asphalt, and a dandelion pushed its flower and leaves through this viscous mass.

Ferndene, December 28, 1879

R. S. NeWALL

\section{Hungarian Earthquakes and the Kolumbács Flies}

A Note in NATURE, vol. xxi. p. 89, speaking of the recent Hungarian earthquakes, contains, amongst others, the following passage :- "Near Weisskirchen, the old ruins of the Castle of Golubacz have fallen in com pletely, and in the vicinity several caves were rendered inaccessible. These caves were the breeding places of the dreaded Kolumbács mosquitos, and if this insect is thus exterminated the earthquake may, with all the damage it did, have yet been of some use."

This report is based on obvious error, for it is a well-known act that the small (3-4 millim. long) Kolumbáes flies (Simualiz golumbacensis, Fabr.), which, in the southern part of Hungary, especially in the old Banat and the county of Hunyad, cause considerable damage among the pasturing cattle (especially among horned cattle, horses, swine, and sheep), breed by no means in those caves which are to be found around the ancient Galambócz (known nowadays under the name of Golubácz or Kolumbács, on the Servian territory), but in the shallower parts of the waters extending in great quantities in that country. The course of life of the Kolumbács fly is, for the most part, in conformity with that of many families of the Nemocera, or Tipulariæ group, as are the Culicidx, -many species of flies (Brachycera), the Phryganidæ, \&c. The mature and fecundated mother-fly lays her eggs upon the plants vegetating on the water-borders, whence they get on the stones under the water, and other objects, there living through their larva and nymph states until they arrive at their full development.

But, in the first years after 1850 , under the rule of the Austrian military system of that time, there did occur the curious fact that -upon the advice of a military officer of the frontier-districts, who, as it was supposed, had made out that the breeding-nests of these flies are in the caves around Galambócz, Old Moldavia, and their environs-the Government of Vienna officially decreed the walling up of the openings of the caves. And actually they were walled up. But in the next mild spring, the conditions of development being favourable again, the Kolumbács fly appeared and ravaged once more. The Viennese Government, on learning this unpleasant and disappointing news, hastened to amend the blunder, and sent to the place a Hungarian sazant, Vincent Kollár, and a German entomologist, Joseph Mann, to take the question under examination. These, in a brief space of time, succeeded in clearing up the trae state of things, and in gathering such a series, as contained all the stages of the development of the Kolumbarcs fly in numerous specimens. Th.s collection is to be seen now in the entomological section of the Naturalien Cabinet of Vienna, grouped in the best order.

The imputation, therefore, as if it were the Hungarians who had walled ap the orifices of the caves in the vicinity of Galambócz, in order to exterminate the Kolumbács flies by that means-an opinion which, as I, this year, happened to hear at the lecture of an eminent German savant, is propagated even in Germany-is entirely erroneous and without any foundation.

Budapest, December 2

JULiUS LETHÖ

\section{Unconscious Thought}

RESUMING this subject, I again call attention to the circurnstance that unconscious thought in children is more developed than conscious thought, though conscious thought or sensation 